of a British Science Service, either as an independent venture or as a London bureau of Science Service of the United States, had long been desired by the director of Science Service, Mr. Watson Davis, and after a necessary period of preliminary discussion and experiment an organisation in the second form has recently been opened at 102-5 Shoe Lane, London, E.C.4, under the direction of Mr. Donald Caley. About twenty representatives of different departments of pure and applied science, including Sir F. G. Hopkins, president of the Royal Society, have consented individually to act in consultative capacities in connexion with this London organisation. The co-operation of scientific workers with the new venture is invited, by supplying information relating to researches on which they are engaged (such information to be treated as confidential when and for as long as desired) ; sending advance proofs of original communications to scientific journals which they edit or control, or regular copies of the journals, which will invariably be mentioned in nowspaper summaries; and to make to Mr. Donald Caley any suggestions which may help him to increase the scope and usefulness of the organisation.

\section{Cultural History in Nebraska}

IN another column of this issue (see p. 555) there appears a brief summary of certain conclusions as to cultural sequences in Nebraska, United States, which have emerged as a result of a review of the archæology of that State by Mr. W. D. Strong. It does less than justice to a record of remarkable interest. Among the numerous investigations of recent date, to which Mr. Strong refers, is that of Signal Butte, a stratified site examined by himself, on which evidence of three distinct cultures is to be observed. The levels in which these are found are separated from one another by deposits of झolian origin, the whole series being superimposed upon sands, which Mr. Strong himself holds to be waterborne and of Pleistocene age. The level of the earliest human occupation is immediately superimposed on these sands. The interpretation of the deposits in terms of climatic variations, based on a correlation with data from other sources, postulates for the whole series, beginning with the period of earliest human occupation, a period of 7,000-10,000 years. Further, this is the only site as yet discovered in America on which stratification gives a clue to the progressive development of type implements of stone in chronological succession. No less interesting and revolutionary in its geographical, archæological and historical implications is a discovery, which hitherto has escaped the attention of archæologists, that while there was a hunting culture on the plains dependent on the bison, in the earliest and in the latest phase of aboriginal existence until it was swept away by Caucasic culture, there intervened between early and recent hunters a semi-horticultural mode of life, akin to that of the Eastern Woodland type, which was forced back to the Missouri with the coming of the horse. This carries with it implications, fully elaborated by Mr. Strong, which necessitate a modification of current views on geographic controls in the Plains area.

\section{Primitive Traits in Amerindian Skulls}

IT is now generally accepted that no skeletal remains of the genus Homo other than those of 'modern' man have hitherto been found on the American continent. Since the arguments put forward by Ameghino early in the present century in support of the primitive character and high antiquity of the skulls he had found in South America were shown by Dr. Ales Hrdlička to be untenable, it has been claimed from time to time that human remains exhibiting characters other than those of Homo sapiens have been discovered; but invariably closer examination of the evidence has failed to support this interpretation. One of the latest discoveries of this nature is that of a fragment of a skull found by Dr. Earl H. Pell, of the Nebraska University, in a large mound of unknown age near the site of a prehistoric village in Nebraska. The skull was that of a middle age man which showed abnormally highly developed eyebrow ridges, intermediate in degree between Neanderthal man and 'modern' man. On the evidence of these supra-orbital ridges it was at first thought that the skull might be included in the Neanderthal group. It has now been subjected to a close analysis by Dr. Hrdlicka, whose decision is not only adverse to any close affinity with Neanderthal man, but definitely rules that it comes within the 'modern' group, on the evidence that in all its characters, excepting the eyebrow ridges, it belongs to the type of the modern Indian. In discussing the skull (Amer. J. Phys. Anthrop., 20, 2), Dr. Hrdlička goes on to point out that while the high development of these ridges may be regarded as evidence of "an ancestral connection with Neanderthal Man somewhere outside America" it does not show uninterrupted filiation, nor can it serve as an index of antiquity.

\section{Recent Acquisitions at the British Museum, Bloomsbury}

Among the recent additions of archæological interest, which are described in the British Museum Quarterly, 10, 1, is a striking example of the artistic ability of the early Maya in the form of a cup with painted ornament, which has additional claim to attention in the fact that it comes from so far south as San Salvador. Especially important for students of early Buddhist art in India is a series of stucco figurines, twenty-five pieces in all, of which eighteen are heads, obtained by the French Archæological Delegation in Afghanistan in 1926-28, at Hadda, about five miles south of Jalalabad. In accordance with the policy, foreshadowed at the time of the acquisition of the Eumorfolpoulos collections, of devoting space in the Quarterly from time to time to descriptions of especially important examples of the art and culture of the Far East, two notes with illustrations deal respectively with a bronze of the Chou dynasty (1123-249 B.c.) and painted bricks of the succeeding Han dynasty. The bronze bowl or tui for holding cereals on ceremonial occasions, 
such as the worship of ancestors, is one of the finest of the few which exist outside the Peiping Palace collections, and is otherwise remarkable in that it has four handles. It is highly ornamented with conventionalised designs including elephant heads and, possibly, stylised tigers. It has an inscription of sixty-nine characters, which is perfectly legible, though interpretations vary. The bowl would appear to commemorate a grant of land, for services rendered, to the Marquis Hsing by an emperor, conjecturally identified as Ch'êng (1115-1078 B.c.) The group of three painted bricks form a pediment which comes from a Han tomb. On them is a free and spirited symbolical design which is here interpreted as expressing the form taken by the Taoistic belief in life after death under that dynasty.

\section{The Typhoon of September 21, 1934, in Japan}

WHAT is described as the greatest typhoon on record struck the southern coast of Japan early on September 21. A week later, the Earthquake Research Institute sent several of its members to the district, and their reports on various features of the typhoon are included in a special volume of the Institute's Bulletin (Suppl. vol. 2, 302 pp. and 34 pls.). All the nine memoirs are written in Japanese, but, with two exceptions (mainly in tabular form), they are followed by summaries in English. The typhoon was generated at sea, in about lat. $11^{\circ} \mathrm{N}$., long. $141^{\circ} \mathrm{E}$., on September 13. It was then weak, and travelled slowly towards the north-west. A week later, near the Ryukyu Islands, its course changed to northeast. When it reached Sikoku, on the southern coast of Japan, its centre showed a pressure of $22.4 \mathrm{in}$., probably a record for land stations. The typhoon then passed over the adjoining districts, causing much damage to houses and trees, but it is worthy of notice that some earthquake-proof school buildings withstood a gale of 134 miles an hour. The main damage occurred in the coastal districts, and was due partly to the sea-waves, or kaze-tunami, raised by the typhoon and partly to a sudden rise of the sea that at Osaka ranged from $9 \cdot 5$ to $18 \cdot 7 \mathrm{ft}$., and at Kobe from $5 \cdot 8$ to $6 \cdot 5 \mathrm{ft}$. Among the causes of this abnormal rise, Mr. R. Takahasi includes a suction-like action on the sea-water due to the low pressure in the centre of the typhoon-path and the drift of the water to the coast by the force of the winds. Farther on, the typhoon passed over Lake Biwa, generating seiches with amplitudes of $10 \mathrm{in.}$ and a rise of the same amount in the northern half of the lake, due again to the drift of the water. Even in the neighbourhood of Tokyo, the sea-level rose by about $4 \mathrm{ft}$.

\section{British Association Seismological Committee}

During the past year, the Committee has lost two of its members, Sir Horace Lamb and Prof. H. M. Macdonald. Two former members, Sir Alfred Ewing and Sir Arthur Schuster, also died since the last report was issued. The year has been marked by the publication of some important memoirs by members of the Committee. Two of them are on microseisms by Mr. A. W. Lee, who has shown that the average amplitudes of the east and vertical components of the microseisms recorded at Kow in 1932 were equal. and that microseisms usually approach England from the north-west, and are associated with storms in the Atlantic. A valuable memoir on the times of transmission of earthquake waves by Dr. H. Jeffreys and Mr. K. E. Bullen has been published by the International Seismological Association (Trav. Scie., Sec. A, Fasc. 11 ; 1935), the inclusion of the summaries for individual earthquakes having been rendered possible by a grant from the Gray-Milne fund. A new catalogue of earthquakes, for the years 1925-30, has been prepared by Miss E. F. Bellamyfrom the International Seismological Summary. The form is the same as in the earlier number for 1918-24, edited by Prof. Turner, of which it is a welcome and very useful continuation. The International Seismological Summary for the first quarter of 1931 is in the press.

\section{River Dee (Aberdeenshire) Flow Records}

THE private organisation under the direction of Capt. W. N. MeClean, known as River Flow Records, has continued its survey of the River Dee, under. taken in connexion with the British Association meeting at Aberdeen in September last year, and has recently issued two sheets of diagrams covering the period January-June inclusive of this year, together with an explanatory memorandum which states that the diagrams represent readings of waterlevels and river flows from a catchment area of 528 square miles, and that they include meteorological records of rainfall, temperature and wind over the same district. As the result of the study of these observations of the Dee area, which have now been kept for a year and a half, it is found that in a comparison of rainfall and run-off, the former is underestimated. There is no actual measurement on the high mountains, and it may be said that rainfall measured in a rain-gauge is generallyunder-estimated; so that rainfall is admittedly only an approximation, whereas the measurement of flow by means of 'the most perfect apparatus existing in the country' is comparatively accurate. In the six months' period, the net aggregate of storage and run-off has reached just less than 19 in. out of a gross rainfall of $22 \frac{1}{2}$ in.

\section{Electric Progress in Palestine}

Lord Reading, the chairman of the Palestine Electric Corporation, said at the annual general meeting on September 5 that electricity has played a leading part in the rapid economic development of Palestine. Last year the Corporation's revenue increased by 64 per cent, and 13,460 new consumers were connected. The generating plant now exceeds 40,000 kilowatts, and the existing transmission line from the first Jordan power house to Tel-Aviv will, at the present rate of growth, soon become inadequate to meet the consumers' load. Hence, a $12,000 \mathrm{kw}$. turbo-generator with the requisite boiler plant, transformers and switchgear has been ordered, and a second 66,000 kilovolt-transmission line will be 